\title{
Katarzyna Korneluk-Markiewicz
}

http://orcid.org/0000-0002-0538-837X

Akademia Ignatianum w Krakowie

k.m.korneluk@gmail.com

DOI: 10.35765/pk.2021.3403.14

\section{Islandzka völva i staropolska czarownica. Analiza porównawcza}

\section{STRESZCZENIE}

Przedmiotem artykułu jest analiza porównawcza postaci islandzkiej völvy i staropolskiej czarownicy. Informacje zawarte w islandzkich sagach i staropolskich podaniach ludowych udowodniły związek wiedźm $\mathrm{z}$ naturą. Zarówno wizerunek, jak i utensylia oraz praktyki magiczne obydwóch czarownic pozostawały w zgodzie z powyższą hipotezą. Natura jako przestrzeń stanowi wyjątkowy obszar, z którego czarownice mogły czerpać swoją moc oraz pozyskiwać składniki do zabiegów magicznych. Z punktu widzenia krytyki ekologicznej wiedźmy to postaci wykorzystujące przyrodę również do wywierania wpływu na człowieka. Wiara w czarownice spowodowała, że stały się pośrednikami w relacji człowieka z otaczającym go krajobrazem.

SŁOWA KLUCZE: völva, czarownice, praktyki magiczne, magia przyrody, krytyka ekologiczna

\section{AB S T RAC T}

The Icelandic Völva and the Old Polish Witch. A Comparative Analysis

The subject of the article was a comparative analysis of the Icelandic völva and the witch in former Poland. Information contained in Iceland sagas and Polish folk tales have proved the relationship between witches and nature. The image, accessories and magic practices of both witches were consistent with the above hypothesis. Nature as a space was a unique area from which witches could draw their power and obtain ingredients for magical treatments. Therefore, from environmental criticism point of view, witches are characters that use the nature to influence human life. Belief in witches made them intermediaries in man's relationship with the surrounding landscape.

KEYWORDS : völva, witches, magic practices, magic of nature, environmental criticism

Sugerowane cytowanie: Korneluk-Markiewicz, K. (2021). Islandzka völva i staropolska czarownica. Analiza porównawcza. (c) (i) Perspektywy Kultury, 3(34), ss. 221-237. DOI: 10.35765/ pk.2021.3403.14. 


\section{Wstęp}

Przedmiotem artykułu jest porównanie postaci wiedźmy islandzkiej i staropolskiej czarownicy. Analiza została przeprowadzona na podstawie wybranych cech charakterystycznych dla czarownic, a mianowicie ich wyglądu, miejsc przebywania oraz umiejętności i akcesoriów magicznych. Informacji na temat wyobrażeń dotyczących skandynawskiej völvy i polskiej wiedźmy dostarczyły wybrane sagi islandzkie ${ }^{1}$ i polskie podania ludowe ${ }^{2}$. Należy zwrócić uwagę, że w tzw. kulturze ludowej zarówno w Polsce, jak i w Islandii działania magiczne nie były wyłącznie domeną czarownic. Między innymi magia miłosna, zielarstwo, znachorstwo i związana z nimi magia lecznicza były praktykami dość powszechnymi w wiejskich społecznościach i niekoniecznie łączyły się jedynie z postaciami wiedźm. Według ówczesnych wierzeń związek z naturą obydwóch czarownic wyrażał się w przebywaniu w odludnych miejscach oraz w stosowaniu przez nie praktyk magicznych. Zatem wiedźmy mogły wpływać na krajobraz, zjawiska meteorologiczne, faunę i florę oraz na ludzi. Komponenty, potrzebne do zabiegów magicznych, pochodziły z przestrzeni przyrodniczej, a więc nabywały jej szczególnych ambiwalentnych właściwości. Zarówno völva, jak i staropolska czarownica wykorzystywały siły natury do wpływania na człowieka. Wynikiem tego był m.in. pejoratywny odbiór przyrody przez człowieka. Krytyka ekologiczna to narzędzie badawcze służące do analizy literatury pod kątem relacji człowieka ze środowiskiem naturalnym (Barcz, 2012). Wśród staropolskiej i islandzkiej ludności zamieszkującej tereny wiejskie i odludne panowało przekonanie, że przyroda jest przestrzenią nieprzewidywalną. Zatem obawa przed tym, co zewnętrzne i związane z siłami natury, spowodowała powstanie wierzeń w czarownice jako postacie kontrolujące i zamieszkujące świat przyrody.

1 Skaldowie recytowali sagi nt. ważnych wydarzeń oraz wielu innych aspektów - to jest magii czy wróżb (Waśko, 2006, s. 8). Sagi były kultywowane w islandzkich rodach od niepamiętnych czasów i stanowity ważną część tradycji. Nazwa saga pochodzi z języka staroislandzkiego: sogur (Simek, 1993, s. 274). Sagða znaczy 'mówić, opowiadać' (Morawiec i Neubauer, red., 2015, s. 8).

2 Polskie podania ludowe z okresu nowożytnego dostarczyły informacji nt. ówczesnych wierzeń w czarownice. Bazą do niniejszych rozważań były podania ludowe zebrane przez Oskara Kolberga, Ryszarda Berwińskiego oraz materiały etnograficzne opracowane przez badacza kultury ludowej Kazimierza Moszyńskiego. Ponadto do charakterystyki postaci czarownicy zostały wykorzystane podania świętokrzyskie opracowane w 1913 r. przez Marię Poraską oraz baśnie i legendy zebrane przez współczesnego badacza - Zenona Gierałę. Miesięcznik geograficzno-etnograficzny „Wisła” wydawany w latach 1887-1905 i 1916-1917 również stanowił źródło informacji dotyczących wierzeń w czarownice. 


\section{Porównanie definicji: völva i czarownica}

Völva to wieszczka i nosicielka różdżek (wand-bearer). Pod względem etymologicznym nazwa vọlva pochodzi od staroislandzkiej nazwy różdżki vọlr (Simek, 1993, s. 279). Kompilatorzy islandzkich sag nazywali kobiety mianem heiðr, co oznaczało 'czarownicę posługującą się magią seiðr' (Simek, 1993, s. 279). Zatem völva była przedstawiona w sagach jako kobieta o magicznych zdolnościach i w literaturze skandynawskiej występowała jako przedstawicielka istot półdemonicznych. Najstarsza forma nazwy czarownica to ze starogermańskiego hagazussa, co znaczy mniej więcej 'stara kobieta latająca na żerdzi z płotu' (Bracha, 2015, s. 130). W Polsce wiedźmy, które porywały dzieci, nazywano również wieszczycami. Inne określenie to widźma, czyli 'wszystko wiedząca lub widząca' (Szot-Radziszewska, 2015, s. 299). Staropolskie czarownice organizowały sabaty na szczytach gór (np. Łysej Góry), na które zmierzały, lecąc na miotle, kiju lub ożogu (Moszyński, 1934). Zatem powyższa próba zdefiniowania islandzkiej völvy i polskiej wiedźmy wykazała, że obydwie istoty miały dar przewidywania przyszłości.

Według definicji pochodzącej ze Stownika mitów i tradycji kultury Władysława Kopalińskiego:

$J e ̨ d z a$ to jedyna zachowana w języku pierwotna nazwa spośród licznych nazw boginek (...) mitologii słowiańskiej, oznaczająca niegdyś żeńskiego demona nasyłającego kolkę, kłucie, ból, chorobę; baba-jaga, wiedźma, czarownica (Kopaliński, 1997, s. 871).

Czarownica występuje w bajkach folklorystycznych w roli Baby-Jagi, jako 'zjadarka' dzieci (Wróblewska, red., 2018). Różnica między nimi polegała na tym, że ta pierwsza porywała i zabijała niemowlęta w celu uzyskania magicznych składników, natomiast Baba-Jaga tylko się nimi żywiła.

\section{Wygląd}

Główną tematyką Sagi o Eryku Rudym były losy pierwszych wikińskich kolonistów. Opowieść dotyczyła m.in. odkrycia Grenlandii oraz dopłynięcia do wybrzeży Ameryki Północnej, którą ówcześnie nazwano Winlandią. Trudne warunki życia i nieurodzaj na Grenlandii były głównymi problemami mieszkańców. Dlatego postanowiono zasięgnąć rady u wieszczki. Z tego powodu wódz Thorkell wyprawił ucztę, na którą zaprosił völvę o imieniu Thorbjörg. Mieszkańcy osady spodziewali się, że otrzymają od niej informację na temat przyszłego urodzaju. Zapraszanie na 
uczty osób praktykujących magię było ówcześnie w powszechnym zwyczaju. O tym, jak ważne były odwiedziny wieszczki, świadczyły specjalne przygotowania:

Przygotował jej odpowiednie miejsce, jak to było w zwyczaju, gdy goszczono niewiastę tego rodzaju. Przygotowano dla niej wysoki stolec, na którym położono poduszkę, wypchaną kurzym pierzem (Waśko, 2006, s. 53).

Siedzisko, na którym siedziała völva, służyło do praktyk magicznych i nazywano je seidðhjallr (Simek, 1993). Według wierzeń bogini Freya była wieszczką i znawczynią magii seiðr. Poduszka napełniona pierzem mogła być analogią do magicznej peleryny z sokolich piór należącej do Freyi (Kempiński, 2003). Dzięki magicznej mocy piór bogini otrzymywała umiejętność latania, natomiast völva zyskiwała dar przepowiadania przyszłości. Adrian Devine określa zdolność wieszczenia jako doświadczenie mistycznego lotu, który może odbywać się podczas ekstatycznego snu oraz dzięki posiadaniu poduszki z pierzem (Devine, 2003). Innymi magicznymi utensyliami wieszczki były różdżka i ubiór:

Gdy przybyła pod wieczór (...) była tak odziana: miała na sobie błękitną wiązaną u szyi kapę, naszytą kamieniami aż do skraja, na szyi miała szklane paciorki, na głowie kaptur z czarnej jagnięcej skórki, obramowany od spodu białym futrem kocim. W ręku dzierżyła [kostur - K.K.-M.] zwieńczony guzem; był on udekorowany mosiądzem, a wokół guza osadzono kamienie. $\mathrm{W}$ talii miała pas uczyniony $\mathrm{z}$ hubki, a na nim wielką sakwę, w której trzymała czarodziejskie przedmioty, niezbędne przy wieszczeniu i magii. Na stopach miała futrzane trzewiki z cielęcej skóry z długimi, mocnymi sznurowadłami, zakończonymi guzami z cyny, a na rękach rękawiczki z cielęcej skórki, wewnątrz białe i włochate (Waśko, 2006, s. 53).

Niebieska barwa stroju wieszczki miała symboliczne znaczenie. Skandynawowie uważali ten kolor za magiczny. Głównie kojarzono go ze śmiercią i mitycznym światem podziemnym należącym do bogini Hel (Devine, 2003). Podczas wieszczenia völva zawsze miała na głowie kaptur. Wykończenie ubrań kocim futrem również miało znaczenie. Zwierzę to było ówcześnie uważane za związane ze światem bogów, np. bogini Freya przemierzała nieboskłon w rydwanie ciagniętym przez dwa koty (Kempiński, 2003). Kolejne akcesorium magiczne völvy to kostur, który służył do odprawiania czarów. Kawałek suchego drewna, znajdujący się obok jej torby, również wykorzystywała do praktyk magicznych. Wyrazem zamożności wieszczki był strój wykończony drogimi kamieniami oraz zdobieniami z mosiądzu. Na uwagę zasługuje również sposób jej zachowania 
się podczas uczty. Według treści sagi völva niewiele mówiła i reagowała na witających ją ludzi w zależności od tego, czy jej się spodobali. Przygotowano dla niej miejsce przy stole (siedziała wyżej od reszty biesiadników) oraz specjalną strawę:

Była to kasza na owczej siarze i - jako danie mięsne - serca wszystkich istot, które były na podorędziu. Widząca miała mosiężną łyżkę i nóż z rękojeścią z kości wielorybiej, przymocowaną do ostrza dwoma miedzianymi pierścieniami, z ułamanym końcem (Waśko, 2006, s. 53).

Według zwyczaju przy stole zasiadano zgodnie z panującą hierarchią społeczną; wysokie siedzisko, na którym siedziała wieszczka, świadczyło więc o jej wysokim statusie społecznym. Najlepszą zastawę stołową również zarezerwowano tylko dla niej. Posiłek złożony z serc wszystkich gatunków zwierząt dostępnych w osadzie służył jako element rytuału. Dopiero po jednej nocy spędzonej w osadzie wieszczka mogła przepowiedzieć przyszłość. Magiczny rytuał odprawiano w celu przywołania duchów opiekuńczych, które miały przekazać wieszczce informacje o przyszłych losach mieszkańców. W tym celu należało stanąć w okręgu i zaśpiewać pieśn Vardlokur. Ostatecznie Thorbjörg przepowiedziała, że na wiosnę ponownie zapanuje urodzaj.

Ponadto ludzie przychodzili do völvy po indywidualne porady:

Ludzie podchodzili do widzącej i pytali o to, co radzi byliby wiedzieć. Chętnie im odpowiadała i naprawdę niewiele z tego, o czym mówiła, nie sprawdziło się (Waśko, 2006, s. 55).

Zatem wieszczki były darzone zaufaniem oraz wierzono w ich nieomylność.

Wizerunek staropolskiej czarownicy został ukształtowany przez wierzenia panujące w polskiej społeczności. W podaniach ludowych występuje często jako uosobienie brzydoty i złych mocy. Według Kazimierza Moszyńskiego czarownicami były najczęściej kobiety mieszkające na wsi:

Wiejskie kobiety usposobienia złośliwego, mściwego, zazdrosnego albo też małomówne, posępne, stroniące od otwartego obcowania z ludźmi (zwłaszcza o ile przytem sama natura napiętnowała je jakowemiś odrażającemi znamionami!) wszędzie, jak Słowiańszczyzna długa i szeroka, są lub niedawno jeszcze były podejrzewane o czary (Moszyński, 1934, s. 652$)^{3}$.

3 Pisownia oryginalna. 
Za wiedźmy uważano zatem kobiety antyspołeczne oraz posiadające znamiona na ciele. Brzydota czarownicy odpowiadała jej złośliwemu charakterowi:

Powierzchowność jej odrażająca: twarz nabrzmiała (...) włosy u niej w wielkim nieładzie, zlepione najczęściej w kołtun, spadają na ramiona (Szot-Radziszewska, za: Siarkowski, 2015, s. 294).

Zgodnie z powyższymi opisami völva i staropolska czarownica różniły się przede wszystkim pod względem aparycji. Ta pierwsza wyglądała dostojnie, natomiast druga nieestetycznie. W podaniach ludowych zebranych przez Zenona Gierałę znajduje się wzmianka o ubiorze czarownicy:

Leciały czarownice na łopatach, miotłach, ożogach i zwykłych kijach (...). Czarownica (...) na tę okazję włożyła ciemnoniebieski płaszcz ze złotymi znakami, podtrzymywany pasem wykonanym z okragłych zasuszonych purchawek $-z$ takich samych purchawek zrobiony był także naszyjnik, na którego końcu wisiał skórzany woreczek z amuletami (...). Całość uzupełniał czarny kapelusz z szerokim rondem, nadając jej postaci wygląd godny i poważny (Gierała, 2018, s. 60).

Wiele podobieństw między islandzką wieszczką i polską wiedźmą widać w elementach ich ubioru. Zarówno völva, jak i czarownica nosiły niebieski płaszcz. Obydwie wiedźmy przechowywały magiczne akcesoria w torbie lub w woreczku. Zamiast drewnianej hubki staropolska czarownica nosiła zasuszone purchawki, a w miejscu kostura - miotłę. Skandynawski kaptur zastąpił polski kapelusz o szerokim rondzie. Kostur völvy służył do czarowania, natomiast staropolska czarownica używała miotły jako akcesorium do latania.

Podania ludowe zebrane i opracowane przez Marię Poraską dostarczyły informacji nt. przepowiadania przyszłości przez polskie wiedźmy:

W przeznaczone na odprawianie modłów dni gromadził się tu liczny lud słowiański (...), aby składać ofiary bogom, przysłuchiwać się pieśniom przy graniu na gęślach śpiewanym, sięgać rad u wróżbitów i wiedźm przepowiadających przyszłość (...). W wigilię św. Jana urządzano obchód sobótek (Poraska, 1913, s. 74, 75).

Zatem obydwie widzące przebywały wśród ludzi podczas ważnych okoliczności (islandzkich uczt, polskich sobótek) w celu przepowiadania przyszłości. W społeczności wikińskiej i w polskiej zdobywanie informacji o przyszłych losach było czymś mile widzianym. Omówione w niniejszym podrozdziale wizerunki czarownic były związane z przyrodą, 
o czym świadczyły naturalne elementy ubioru (skóry i futra zwierzęce, drewniane akcesoria).

\section{Umiejętności magiczne}

Wydarzenia rozgrywające się w Sadze o Hedinie i Högnim stanowią przykład użycia magii z powodów osobistych i w celu wywołania ludzkiej tragedii. Konflikt bogini Freyi z Odynem doprowadził do wybuchu wojny między królami Hedinem i Högnim. W zamian za skłócenie władców Freya miała odzyskać swój magiczny pierścień. Doprowadziła do tego, podając Hedinowi przeklęty napój. W opowieści Freya ukazała się pod postacią wieszczki o imieniu Göndul. Siedziała w lesie na wysokim tronie i oczekiwała na przybycie Hedina:

Trzymała róg; był on zakryty wieczkiem (...) poprosiła, by się napił (...) a gdy to zrobił, zaszła w nim wielka zmiana, gdyż nie pamiętał o niczym (...) Tak był Hedin zniewolony przez niegodziwość i czar zapomnienia (Leśniakiewicz-Drzymała, 2016, s. 12).

Z etymologicznego punktu widzenia nazwa magii seiðr może odnosić się także do angielskiego czasownika seethe, który oznacza 'wrzenie wody' (Devine, 2003). Zatem praktyki magiczne były związane z przygotowywaniem magicznych mikstur. W konsekwencji wypite przez Hedina zaczarowane piwo odebrało mu pamięć, co spowodowało wybuch niekończącej się wojny pomiędzy nim a jego przyjacielem.

Staropolska czarownica również była związana ze środowiskiem naturalnym. Szczególnie widać to na przykładzie sabatów, które odbywały się na tzw. łysych górach. Według Stownika symboli góra oznacza granicę z zaświatami i jest porównywana do osi świata (axis mundi) łączącej ziemię i niebo. W Polsce panowało przekonanie, że czarownice tworzyły grupy, o czym świadczyły ich spotkania na sabatach. Z kolei islandzkie wiedźmy nie tworzyły tego typu zgromadzeń. Wieszczka Thorbjörg zajmowała się praktykami magicznymi wraz ze swoimi siostrami, a więc $\mathrm{w}$ gronie rodzinnym.

Czarownice miały być odpowiedzialne m.in. za: wywoływanie uroków miłosnych, zsyłanie chorób, kradzież mleka, niszczenie plonów (Wróblewska, red., 2018). Z podań ludowych zebranych przez Oskara Kolberga wynika, że wiedźmy zajmowały się przygotowaniem magicznych mikstur: 
Cudowniejszem może zielem jest sławny Lubystek, czyli Lubcyk (Sigusticum officin.) w którem matki kąpią córki, żeby dorosłszy, chłopakom się podobały - albo też tak zwany Nasieźrał (Ophioglossum vulgatum), który zdobywa dziewczętom wzajemność serc najbardziej nieczułych i obojętnych (Kolberg, 1886, s. 200) ${ }^{4}$.

Według polskiej tradycji ludowej czarownice używały lubczyku jako zioła. Podanie do wypicia odwaru z lubczyku mogło np. wzbudzić miłość w mężczyźnie. Zioła, które były stosowane do przygotowywania mikstur miłosnych, to głównie lubczyk, pokrzyk i nasięźrzał. Wiedźmy pozyskiwały magiczną moc od diabła podczas warzenia ziół:
Aby nabyć moc czynienia czarów od Lucypera, czarownice w nocy z Wiel- kiego Piątku na Wielką Sobotę zbierają się o 13 godzinie w lesie na krzyżo- wej drodze, gdzie warzą w kotłach nasięźrzał z macierzanką i miętą (...). Nasięźrzał uzbierany z 7 lasów, macierzankę z 7 miedz i miętę z ogrodów (Bartmiński, red., 2019, s. 249, 250) ${ }^{5}$.

Kolejną magiczną zdolnością islandzkiej wieszczki i staropolskiej czarownicy była umiejętność latania. Na podstawie treści sag wiadomo, że völva doświadczała mistycznego lotu w zaświaty tzw. gandreip (gandreið oznacza 'jazdę na kołku'). Motyw lotu gandreip znajduje się w Sadze o Njalu (Brennu-Njáls saga) i jest związany z okrutną zemstą. Tytułowy bohater miał zostać spalony wraz z synami we własnym domu. Według wieszczki należało zniszczyć stos suchej trawy, ale Njal zignorował jej ostrzeżenie. Finalnie, na nocnym niebie pojawił się jeździec na szarym koniu:

Na zachodnim sklepieniu nieba (...) pierścień a w nim jeździec na szarym koniu. Jeździec był czarny jak smoła (...) rzucił żagiew na góry na wschodzie i buchnął pożar płomieniem tak wysokim, że gór widać nie było (...) on ukazuje się, gdy mają dziać wielkie wydarzenia (Załuska-Strömberg, 1968, s. 255).

Pojawienie się jeźdźca na niebie zapowiadało ważne wydarzenie spalenie domu Njala. Badaczka kultury skandynawskiej Hilda Roderick Ellis Davidson wskazała w jednym z artykułów dotyczącym islandzkiej magii, że motyw jeźdźca-ducha z płonącą żagwią mógł mieć wpływ na powstanie motywu czarownicy jeżdżącej na kiju (Ellis Davidson, 2013). Motyw lotu można prześledzić również w innych źródłach. Na przykład

4 Pisownia oryginalna.

5 Pisownia oryginalna. 
związek z powyższym tematem miał germański duch zunritten (w dosłownym tłumaczeniu: ‘jeździć na płocie’). Kolejnym nawiązaniem do wyżej wymienionego ducha i motywu lotu jest szwedzki dokument pochodzący z 1170 r. Piętnował on kobiety, które pod postaciami trolli unosiły się w powietrzu na kołkach (Bracha, 2015).

Dodatkowo za pomocą drewnianego kostura (różdżki) völva mogła wywoływać u ludzi choroby, jak również poruszać się w czasie i przestrzeni pod postacią zwierzęcia (Bracha, 2015). Drewniany kołek służący do latania stanowił fragment płotu, który pochodził z przestrzeni granicznej. Zatem kawałek drewna wykazywał wyjątkowe cechy przestrzeni, z której pochodził, co implikowało jego magiczne zastosowanie.

$\mathrm{Na}$ gruncie polskim panowało przekonanie, że umiejętność latania czarownic była możliwa dzięki zastosowaniu specjalnej maści i zaklęcia: „Płot nie płot, wieś nie wieś, biesie nieś!” (Moszyński, 1934, s. 652).

Magiczną pomadą zmieszaną z ziołami należało posmarować pachy. Powyższy zabieg miał umożliwić wzbicie się w powietrze. Przepis na maść ilustruje poniższy cytat:

Wszystkie czarownice oskarżano o dzieciobójstwo, które popełniać miały, dlatego, że chcąc lecieć na łysą górę na łopacie lub miotle, smarować się poprzednio musiały maścią, którą smażyć mogły z pewnych ziół tylko w tłustości dzieci, przed chrztem uduszonych (Berwiński, 2019, s. 14, 15) ${ }^{6}$.

Zanim czarownice zaczęły korzystać z drewnianych akcesoriów służących do latania, istniał inny środek transportu o jeszcze starszej proweniencji. Średniowieczni mnisi Reginion z Prüm i Burchard z Wormacji wskazali, że pierwszym środkiem służącym czarownicom do latania był grzbiet zwierzęcy. Bogini Diana, którą czczono w starożytnym Rzymie, również wykorzystywała magiczną umiejętność latania (Bracha, 2015). W mitologii słowiańskiej występuje podobna postać do rzymskiej bogini Diany. Jan Długosz w swojej kronice utożsamił ją ze staropolską Dziewanną:

Rozległe lasy i gaje, o których starożytni wierzyli, że zamieszkuje je Diana i że rości sobie władztwo nad nimi, Cerera zaś uważana była za matkę i boginię urodzajów (...) te dwie boginie: Diana w ich języku Dziewanną zwana i Cerera zwana Marzanną cieszyły się szczególnym kultem i szczególnym nabożeństwem (Gieysztor, 2006, s. 195).

Wracając do sposobu wykonywania magicznych przedmiotów, należy zwrócić uwagę na miotłę czarownicy. Islandzki kołek służący do latania

6 Pisownia oryginalna. 
pochodził z płotu, natomiast miotłę wykonywano z wierzbowych gałązek. Według wierzeń w niektórych gatunkach drzew osiedlały się złe moce. Czarownice używały wierzbowych witek do plecenia sit, służących do wypraw morskich (Kopaliński, 1990, s. 464). Z kolei islandzka wiedźma używała drewnianego kostura do wpływania na środowisko naturalne, np. do zawracania biegu rzek, powodowania sztormów i osuwisk terenu.

Saga o Ludziach z Vatnsdal (Vatnsdala Saga) opisuje losy islandzkiego rodu oraz walkę głównego bohatera u boku norweskiego króla Haralda Pięknowłosego. Na szczególną uwagę zasługuje tutaj wątek dotyczący czarownicy o imieniu Groa, która dokonała zmian w krajobrazie. Chodzenie wokół domu w kierunku przeciwnym do ruchu wskazówek zegara, specjalne zaklęcie („teraz niech nadejdzie to, co jest gotowe”) oraz wymachiwanie chusteczką ze złotym węzłem spowodowało zapadnięcie się ziemi (Ellis Davidson, 2013). Innym dziełem zawierającym opisy niektórych zabiegów magicznych oraz historię kolonizacji Islandii jest Księga o Zasiedleniu (Landnámabók). W tym przypadku zaklęcia spowodowały zmiany w islandzkim krajobrazie - cofanie się wody. Czynności magiczne polegały na zanurzeniu czubka magicznego kostura w wodzie i ugryzieniu jego mosiężnego okucia (Ellis Davidson, 2013).

W staropolskich podaniach ludowych znajduje się również informacja nt. użycia magicznej chusteczki przez czarownice:

Dzięki czerwonej chustce [kosturowi - K.K.-M.] posmarowanemu czarną maścią, za sprawą cienkiego sznura rozrasta się masło (Moszyński, 1934, s. 371).

Staropolskie wiedźmy miały zdolność pozyskiwania mleka lub masła z przedmiotów, np. za pomocą sznura i specjalnej chusteczki. Zatem akcesoria magiczne obydwóch czarownic były wykonywane z naturalnych elementów, w których tkwiła tajemna moc.

Zarówno islandzkie völvy, jak i staropolskie czarownice stosowały techniki magiczne, które wpływały na pogodę. Kontrolowanie zjawisk meteorologicznych wiązało się z możliwością powodowania: sztormów, wichur, burz, zawiei śnieżnych itp.

Saga o Fridthiofie Śmiatym to opowieść o młodym wikingu, który naraził się na zemstę rodziny swojej ukochanej. Przeciwnicy Fridthiofa próbowali go zabić za pomocą magii. W związku z powyższym dwie wiedźmy Heid i Hamglama wpływały na warunki pogodowe na morzu:

Posłali po dwie czarownice Heid i Hamglamę, zapłacili im suto, by sprowadziły na Fridthiofa i załogę huragan taki, że wszyscy zginą (...) Zaczęły zamawiania i śpiewając pieśni złowieszcze, weszły na wysoką kazalnicę, potem długo wypowiadały zaklęcia. (...) Zerwał się ostry wiatr 
i rozpoczęła się burza (...). Niewiasty dwie widzę na grzbiecie wieloryba; one to z całą pewnością zamawianiami i czarami zesłały na nas wszystkie te nieszczęścia (Załuska-Strömberg, 1974, s. 34, 37, 38).

Manipulacja zjawiskami meteorologicznymi oraz zachowaniem zwierząt miała spowodować unicestwienie całej załogi statku.

W nowożytnej Polsce czarownice równiė̇ wywierały wpływ na warunki pogodowe. Jako przykład posłużył fragment z podań ludowych zebranych przez Oskara Kolberga. W dziele Lud, jego zwyczaje, sposób zycia, mowa, podania, przystowia, obrzędy, gusta, zabawy, pieśni, muzyka i tańce w tomie trzecim, w części pierwszej pt. Kujawy znajduje się fragment ukazujący wpływ wiedźm na pogodę:

Postrzelił [strzelec - K.K.-M.] ją [gęś - K.K.-M.] w skrzydło (...) i poznawszy, że to [czarownica - K.K.-M.], babę zagnał do Urzędu (...). Wyjęto potem z gniazda trzy pozostałe w nićm jaja i takowe we wsi roztłuczono. W jednem jaju znaleziono krew (wojnę), w drugićm grad (nieurodzaj), a w trzeciem deszcz (zalew). Czarownicę oćwiczono rózgami (Kolberg, 1867, s. 102) ${ }^{7}$.

Zatem wiedźma, pod postacią gęsi lub kruka, wysiadywała jaja w celu sprowadzenia deszczu albo gradu. Niektóre zjawiska atmosferyczne były niebezpieczne zarówno dla życia ludzi, jak i dla upraw (Bartmiński, red., 2012). Wierzenia w ingerencję czarownic w pogodę powodowały lęk wśród ludzi przed utratą plonów.

Inną umiejętnością magiczną völvy było pojawianie się pod postaciami zwierząt, np. kota, sokoła, dzika, morsa, a nawet wieloryba. W wielu kulturach tę zdolność magiczną utożsamiano z szamanizmem. Magia seiðr miała pewne cechy wspólne $z$ magią szamańską stosowaną przez ludy zamieszkujące tereny Finlandii. Do fińskich wpływów należała m.in. wiara w umiejętność zmiany postaci z ludzkiej na zwierzęcą. Według szamańskiej wiedzy wspomniana przemiana była konieczna, aby móc odbyć podróż do „tamtego świata”, w celu zdobycia wskazówek, w jaki sposób doprowadzić do realizacji upragnionego celu (Tony, 2003). Badacz Allan Tony informuje, że skandynawski lud Saami mógł stosować praktyki religijne związane z szamanizmem:

Świat szamanów - czyli osób, którym w pewnych kulturach przypisuje się umiejętność przemiany w zwierzęta. Szamanizm był rozpowszechniony wśród większości ludów północnej Eurazji. Do kontaktu ze światem skandynawskim doszło najprawdopodobniej za pośrednictwem ludu

7 Pisownia oryginalna. 
Saami, czyli Lapończyków, arktycznych sąsiadów Norwegów oraz Szwedów. Przekazy historyczne zdają się świadczyć o tym, że odległe regiony, które zamieszkiwali Saami, traktowano z pełną przesądów bojaźnią (Tony, 2003, s. 36).

Zatem wierzenia Skandynawów związane z przemianą w zwierzęta mogą wyrastać z dawnego szamanizmu. W wielu islandzkich sagach wiedźmy występują pod postaciami zwierząt, co dobrze ilustruje Saga o Kormaku (Kormáks Saga). Powyższy utwór dotyczy losów tytułowego bohatera, na którego został rzucony urok. Czarownicę o imieniu Thorveig widziano pod postacią wieloryba:

Gdy dwaj bracia opuścili redę, zobaczyli blisko swojego statku wieloryba. Kormák cisnął w niego pałką, która uderzyła bestię tak, że ponownie zatonęła. Ludzie na pokładzie mówili, że ślepia wieloryba to oczy czarownicy Thorveig. Wieloryb już się nie pojawił, ale słyszano, że Thorveig była śmiertelnie chora (Kormáks Saga, http://sagamap.hi.is/is/\#, rozdział 18) ${ }^{8}$.

Wieloryb został raniony, a Thorveig umarła, co według ludzi dowodziło, że potrafiła przemieniać się w zwierzęta.

Z kolei staropolska czarownica mogła się pojawiać pod postaciami: żaby, ropuchy lub ćmy. Przemiana w zwierzę była związana z emanacją duszy wiedźmy, która podczas snu opuszczała jej ciało (Moszyński, 1924). Zdemaskowanie czarownicy zostało trafnie opisane w jednym z artykułów badaczki Elżbiety Szot-Radziszewskiej:

Ojciec zobaczył żabę, jak poszedł doić krowę. Ciachnął ją siekierą w nogę. Okazało się, że w sąsiedniej chałupie sąsiadka [kuleje - K.K.-M.]. To ona czarowała krowę, urok rzucała (Szot-Radziszewska, 2015, s. 297).

Po analizie powyższych źródeł nasuwa się wniosek, że zarówno na dalekiej Północy, jak i w nowożytnej Polsce wierzono, że wiedźmy mogły się pojawiać pod postaciami zwierząt oraz w podobny sposób je demaskowano. Zatem obrażenia, które zadano zwierzęciu, były jednocześnie uszkodzeniami ciała czarownicy. Działania wiedźm w świecie fauny potwierdzały słuszność tezy dotyczącej ich bliskich powiązań z przyrodą.

Zarówno w islandzkim, jak i staropolskim społeczeństwie przypisywano właściwości magiczne procesowi przędzenia. Wracając do nazwy seiđr, należy uzupełnić ją o kolejne znaczenie, a mianowicie mogło być ono związane $\mathrm{z}$ nicią:

8 Aby zobaczyć treść Kormáks Saga, należy otworzyć link: http://sagamap.hi.is/is/\#, następnie wybrać open map i zaznaczyć interesującą nas sagę: Kormáks Saga. 
Podczas praktyki przędzenia, coś za pomocą seiðr przyciągano (...) nici przybierały formę dusz lub duchów wysyłanych w formie nici, aby coś przyciągnąć (Gardeła, za: Heide, 2019, s. 50).

Skandynawskie kobiety wierzyły, że można wplatać zaklęcia w odzienie. Mogły to być zarówno czary ochronne, jak i szkodzące. Informacje na temat praktyk magicznych związanych z przędzeniem potwierdzają islandzkie opowieści. Saga o Orkadach (Orkneyinga saga) opisuje losy wikińskich kolonistów na tytułowych wyspach oraz historię ich podboju przez Haralda Pięknowłosego. Na uwagę zasługuje wątek dotyczący stosowania praktyk magicznych podczas przędzenia:

Helga i jej siostra Frakkok haftowały lnianą koszulę złotymi nićmi wraz z dodatkiem trucizny i złego zaklęcia. Niestety syn Helgi zechciał ją na własność. Siostry ściągnęły czepce $z$ głów, zaklinały go, płakały, aby nie zakładał koszuli, ponieważ może stracić życie. Jednak nie posłuchał i założył zatrute odzienie. Jego ciało zaczęło drżeć i wkrótce umarł w męczarniach (Pálsson i Edwards, 1978, Orkneyinga saga, rozdział 55).

Motyw tkania koszul czarownic tzw. gørningstakkr spotyka się również w innych sagach, np. w Vatnsdcela saga i Eyrbyggja saga. W pierwszym utworze wiedźma Ljót zajmowała się wplataniem zaklęć ochronnych w koszulę dla swojego syna. Z kolei w drugiej opowieści, obok wątku nieszczęśliwej miłości i waśni rodowej, znajduje się przykład stosowania praktyk magicznych podczas przędzenia. Katla wplatała zaklęcia w koszulę, aby chroniła jej syna przed przyszłymi ranami, które mógł odnieść w walce (Korneluk-Markiewicz, 2021). W mitologii skandynawskiej wymienione są trzy postaci wieszczek, tzw. Norn, które tkały ludzki los złotymi nićmi (Gardeła, 2019). Dlatego przędzenie nie było związane jedynie z celami praktycznymi, ale także $z$ magicznymi.

Magia seiðr była zatem przejawem życia codziennego, związana z mentalnością mieszkańców Skandynawii i tkwiąca głęboko w wierzeniach. W związku z wierzeniami o prządkach powstał archetyp złotej nici występującej w ścisłej korelacji z życiem człowieka. Była to magia dostępna dla ludzi, a w szczególności dla kobiet, które zajmowały się warsztatem tkackim (Korneluk-Markiewicz, 2021, s. 99).

W polskiej tradycji ludowej również istniało przekonanie o magicznych właściwościach przędzenia. W tym przypadku rytuał posłużył do ukarania niewiernego mężczyzny:

Wyszła ona z kądzielą przede dwór, stanęła se na drodze i przędzie, a patrzy na tych weselników. A żjak państwom łodzina djechali, ona nitkę 
na przędzioną mig, mig, mig - nawinęła na wrzeciono i krzycy na młodego: $\mathrm{Oj}$, pożałujesz ty jeszce, coś moi Kasi świat zamotał: zamota się i tobie, nie zaznasz doli. Namotała ona na nich, namotała... Zaraz po weselu się podarły ze sobą: on z nio nie chciał siedzić (Staniszewska, 1902, s. 621$)^{9}$.

Do przędzenia używano nici, a zatem składnika naturalnego. Korzystanie z naturalnych materiałów pozyskanych z przestrzeni przyrodniczej umożliwiało wplatanie zaklęć w tkane ubrania. Zarówno w społeczności wikińskiej, jak i w nowożytnej Polsce magiczny proces przędzenia służył do wymierzania sprawiedliwości.

\section{Podsumowanie}

Przeprowadzona w artykule analiza porównawcza islandzkiej völvy i staropolskiej czarownicy potwierdza, że występują one $\mathrm{w}$ bliskich relacjach z przyrodą. Przedstawiony materiał tekstowy pozwolił m.in. wykazać, iż obydwie czarownice zajmowały się przepowiadaniem przyszłości. Zarówno w islandzkiej, jak i w polskiej społeczności, chęć poznawania przyszłych wydarzeń była czymś powszechnie pożądanym. Wizerunek wiedźm związany był również z naturą, co odzwierciedlał ich ubiór, wyposażenie oraz przebywanie na pustkowiach. Ponadto zostało udowodnione, że składniki, z których wykonywano magiczne przedmioty, mikstury, maści etc. nabierały cech przyrody, z której zostały zaczerpnięte. Dzięki temu wywoływały magiczne efekty w sferach: miłości, życia, zdrowia, pogody, gospodarstwa i krajobrazu. Praktyki magiczne islandzkich wiedźm wpływały na wygląd krajobrazu. Natomiast zabiegi magiczne staropolskich czarownic dotyczyły pomnażania mleka i masła. Umiejętność zmiany postaci na zwierzęcą świadczyła o ich bliskim związku ze światem fauny. Zarówno w społeczności wikińskiej, jak i w polskiej, magiczna praktyka przędzenia była stosowana w celu ochrony lub spowodowania śmierci danej osoby. Z kolei wierzenia dotyczące kontrolowania zjawisk meteorologicznych przez czarownice wiązały się ze strachem wiejskiej ludności przed utratą plonów. Jednym z głównych założeń krytyki ekologicznej jako narzędzia służącego do badania literatury jest zwrócenie uwagi na relacje człowieka ze środowiskiem naturalnym. W islandzkich i staropolskich społeczeństwach wierzono, że przyroda jest przestrzenią niebezpieczną. Dlatego ówcześnie panowała powszechna obawa przed czarownicami, wykorzystującymi moce płynące z natury

9 Pisownia oryginalna. 
do oddziaływania na człowieka. Wieszczki były zatem pośredniczkami w relacji człowiek - natura.

\section{BIBLIOGRAFIA}

Barcz, A. (2012). Przyroda - bliska czy daleka? Ekokrytyka i nowe sposoby poetyki odpowiedzialności za przyrodę w literaturze. Anthropos, nr 18-19, 59-79.

Bartmiński, J. (red.). (2012). Stownik stereotypów i symboli ludowych. Kosmos: meteorologia. T. I. Lublin: Wydawnictwo Uniwersytetu Marii Curie-Skłodowskiej.

Bartmiński, J. (red.). (2019). Stownik stereotypów i symboli ludowych. Rosliny: zioła. T. II. Lublin: Wydawnictwo Uniwersytetu Marii Curie-Skłodowskiej.

Berwiński, R. (2019). Studia o gustach i czarach. T. I. Sandomierz: Wydawnictwo Armoryka.

Bracha, K. (2015). Średniowieczna metryka wizerunku świętokrzyskiej czarownicy. W: J. Pietrzak-Thèbault i Ł. Cybulski (red.), Czary, alchemia, opętanie $w$ kulturze na przestrzeni stuleci. Studia przypadków. Warszawa: Wydawnictwo Uniwersytetu Kardynała Stefana Wyszyńskiego, 119-134.

Davidson, E. (2013). Hostile Magic in the Icelandic Sagas. W: V. Newall (red.), The Witch Figure: Folklore essays by a group of scholars in England honouring the 75th birthday of Katharine M. Briggs. London-New York: Routledge, 20-41.

Devine, A. (2003). Magia Celtów i Wikingów. Wrocław: Wydawnictwo Kirke.

Gardeła, L. (2019). Magia, kobiety i śmierć w świecie Wikingów. Szczecin: Wydawnictwo Triglav.

Gierała, Z. (2018). Baśnie i legendy ziemi świętokrzyskiej. Kielce: Wydawnictwo Jedność.

Gieysztor, A. (2006). Mitologia Stowian. Warszawa: Wydawnictwo Uniwersytetu Warszawskiego.

Kempiński, M.A. (2003). Ilustrowany leksykon mitologii wikingów. Poznań: Wydawnictwo Kurpisz.

Kolberg, O. (1886). Dzieła wszystkie. Lud jego zwyczaje, sposób życia, mowa, podania, przystowia, obrzędy, gusta, zabawy, pieśni, muzyka i tańce. T. XIX, cz. 2: Kieleckie. Wrocław-Poznań-Kraków: Polskie Wydawnictwo Muzyczne Ludowa Spółdzielnia Wydawnicza.

Kolberg, O. (1867). Dzieta wszystkie. Lud jego zwyczaje, sposób życia, mowa, podania, przystowia, obrzędy, gusta, zabawy, pieśni, muzyka i tańce. T. III, cz. 1: Kujawy. Wrocław-Poznań-Warszawa: Polskie Towarzystwo Ludoznawcze.

Kopaliński, W. (1997). Stownik mitów i tradycji kultury. Lublin: Wydawnictwo PWZN.

Kopaliński, W. (1990). Stownik symboli. Warszawa: Wiedza Powszechna. 
Kormáks Saga. Pozyskano z: http://sagamap.hi.is/is/\# (dostęp: 23.06.2021).

Korneluk-Markiewicz, K. (2021). Przędzenie, haft i inne praktyki magiczne w życiu codziennym skandynawskich kobiet w średniowieczu, a analogie do symboliki wzoru kolistego - sztuka celtycka i skandynawska. W: M. Iwaniuk i K. Skrzątek (red.), Naukowe rozwaziania o problemach z zakresu filozofii, kultury $i$ historii. Lublin: Wydawnictwo Naukowe TYGIEL, 76-104.

Leśniakiewicz-Drzymała, R. (2016). Opowieść o Sörlim albo Saga o Hedinie i Högnim. Sandomierz: Wydawnictwo Armoryka.

Morawiec, J. i Neubauer, Ł. (red.). (2015). Sagi islandzkie zarys dziejów literatury staronordyckiej. Warszawa: Wydawnictwo Naukowe PWN.

Moszyński, K. (1934). Kultura ludowa Stowian. Cz. II. Kraków: Polska Akademia Umiejętności.

Pálsson, H. i Edwards, P. (1989). Eyrbyggja Saga. Rozdział 20. Londyn: Penguin.

Pálsson, H. i Edwards, P. (1978). Orkneyinga saga. Rozdział 55. Harmondsworth: Penguin.

Poraska, M. (1913). Podania Świętokrzyskie: opracowane wedtug powieści ludowych. Warszawa: Nakład Wieczorów Rodzinnych.

Simek, R. (1993). Dictionary of Northern Mythology. Cambridge: Boydell \& Brewer Ltd.

Staniszewska, Z. (1902). Wieś Studzianki. Zarys etnograficzny. Wista, T. 16, z. 5, 603-634.

Szot-Radziszewska, E. (2015). Ludowy obraz czarownicy świętokrzyskiej w świadomości mieszkańców Kielecczyzny w świetle historycznych i współczesnych źródeł etnograficznych. W: J. Pietrzak-Thèbault i Ł. Cybulski (red.), Czary, alchemia, opętanie w kulturze na przestrzeni stuleci. Studia przypadków. Warszawa: Wydawnictwo Uniwersytetu Kardynała Stefana Wyszyńskiego, 291-303.

Tony, A. (2003). Wikingowie życie, legendy i sztuka. Warszawa: National Geographic.

Vatnsdela saga. Pozyskano z: http://sagamap.hi.is/is/\# (dostęp: 23.06.2021).

Waśko, A. (2006). Saga o Grenlandczykach. Saga o Eryku Rudym. Wikingowie na Grenlandii i $w$ Ameryce. Kraków: Księgarnia Akademicka.

Wróblewska, V. (red.). (2018). Stownik polskiej bajki ludowej. T. 1-3. Toruń: Wydawnictwo Naukowe Uniwersytetu Mikołaja Kopernika.

Załuska-Strömberg, A. (1974). Saga o Fridthiofie Śmiałym. Poezja, nr 10, 28-47.

Katarzyna Korneluk-Markiewicz - studia magisterskie ukończyła w Akademii Ignatianum w Krakowie. Obecnie doktorantka w Szkole Doktorskiej Akademii Ignatianum. Przygotowuje pracę doktorską dotyczącą porównania wizerunku islandzkiej i staropolskiej czarownicy na 
podstawie tekstów kulturowych. Jej zainteresowania naukowe to literatura i kultura staropolska i skandynawska. Autorka rozdziałów w monografiach: Przedzenie, haft $i$ inne praktyki magiczne w zyciu codziennym skandynawskich kobiet $w$ średniowieczu, a analogie do symboliki wzoru kolistego sztuka celtycka i skandynawska; Istoty nadprzyrodzone oraz rola krajobrazu i przyrody w Sadze o Hawardzie z Lodowego Fiordu. 
